\title{
Fluoride Concentration in Public Water Supply: 72 Months of Analysis
}

\author{
Suzely Adas Saliba MOIMAZ \\ Orlando SALIBA \\ Fernando Yamamoto CHIBA \\ Doris Hissako SUMIDA \\ Cléa Adas Saliba GARBIN \\ Nemre Adas SALIBA
}

\begin{abstract}
Public Health Graduate Program, Department of Child and Community Dentistry, Araçatuba Dental School, UNESP - Univ Estadual Paulista, Araçatuba, SP, Brazil
\end{abstract}

\begin{abstract}
Known as one of the ten most important advances on Public Health in the 20th century, fluoridation of public water supply is a measure of wide population coverage, which is effective on caries control. The city of Araçatuba, in the Northwest region of the São Paulo state, Brazil, started public water supply fluoridation in 1972 and, based on the average annual highest temperature, has kept the fluoride concentration between 0.6 to $0.8 \mathrm{mgF} / \mathrm{L}$. The purpose of this study was to analyze monthly the fluoride concentration in public water supply in the city of Araçatuba during 72 months. Water samples were collected monthly on weekdays, directly from the water distribution network, on pre-established locations and analyzed in duplicate between November 2004 and October 2010 at the Research Laboratory of the Nucleus for Public Health (NEPESCO) of the Public Health Graduate Program from Araçatuba Dental School/UNESP, Brazil, using an fluoride-specific electrode connected to an ion analyzer. From the total of samples ( $\mathrm{n}=591)$, $67.2 \%(\mathrm{n}=397)$ presented fluoride concentration between 0.6 and $0.8 \mathrm{mgF} / \mathrm{L} ; 20.6 \%(\mathrm{n}=122)$ below $0.6 \mathrm{mgF} / \mathrm{L} ; 11.5 \%(\mathrm{n}=68)$ between 0.8 and $1.2 \mathrm{mgF} / \mathrm{L}$ and $0.7 \%(\mathrm{n}=4)$ above $1.2 \mathrm{mgF} / \mathrm{L}$. Most samples showed fluoride levels within the recommended parameters. Minimal variation was observed among the analyzed collection locations, showing that the city has been able to control the fluoride levels in the public water supply and reinforcing the importance of surveillance and constant monitoring to assure the quality of the water delivered to the population.
\end{abstract}

Key Words: fluoridation, water, fluoride, oral health.

\section{INTRODUCTION}

The Brazilian population is entitled to the consumption of fluoridated public water supplies since May 24, 1974, by the Federal law No. 6050, which made fluoridation mandatory in all Brazilian cities with water treatment stations (1). However, in Brazil, the addition of fluoride to public water supply started in 1953. Baixo Guandu, ES, was the first city to perform water fluoridation under control of the Ministry of Health Public Health Special Services (SESP) (2).

The addition of fluoride to water supply is a safe, effective and low-cost preventive public health measure for the reduction of dental caries, with a wide population reach (3), being recognized as one of the ten most important advances of Public Health in the 20th century (4). This method is recommended by several organizations such as World Health Organization (WHO), International Dental Federation (FDI), International Association for Dental Research (IADR) and Pan-American Health Organization (PAHO), mainly in countries with high caries prevalence $(5,6)$. However, care must be taken, since excessive exposure to fluoride by water consumption combined with other fluoride sources may result in undesirable effects, such as dental fluorosis (7-9).

To achieve the expected results with this preventive method, a strict control of the process of water fluoridation is required, avoiding the undesirable effects of over-dosage, as well as avoiding underdosage, which does not offer the maximum benefits (2). Therefore, in addition to operational control done 
by the local sanitation company, external control by the Brazilian Health Surveillance Agency (ANVISA) or other institutions, public or private is strongly advised. The external control consists in the control and periodic analysis of the water fluoridation by a different institution which is not the one responsible for the treatment and water supply (10).

Considering that the average maximum annual temperatures in the city of Araçatuba is between $26.3^{\circ} \mathrm{C}$ and $32.5^{\circ} \mathrm{C}$, the fluoride level offering the best riskbenefit combination was $0.55-0.84 \mathrm{mgF} / \mathrm{L}(11,12)$.

Located in the Northwest region of the São Paulo state, Brazil, the city of Araçatuba has 181,579 inhabitants (13) and implemented fluoridation of public water in 1972, being one of the first Brazilian municipalities to adhere to this method.

Due the importance of continuous maintenance of fluoride concentration within the recommended parameters and considering that the analysis of fluoride concentration in public water supply provides accurate information about this important measure to population's oral health, the purpose of this study was to analyze monthly the fluoride concentration in public water supply in the city of Araçatuba, SP, Brazil, during 72 months.

\section{MATERIAL AND METHODS}

This was a longitudinal study, conducted in the city of Araçatuba, SP, belonging to the Regional Health Department II (RHD II), located in the northwest region of the São Paulo State, between November 2004 and October 2010.

Formal and personal contacts were made with the Secretariat of Health, Oral Health Coordinator and Public Water Supply Coordinator, in order to establish partnerships and to obtain information about the water distribution system of the city. According to information provided by people in charge of the public water supply, the city water has been artificially fluoridated since the beginning of the study and for several years before, and the composite used for fluoridation is the fluosilicic acid.

The public water supply system of Araçatuba is composed of 3 different water sources (Fig. 1), two with natural fluoride and the other with artificial addition.

\section{Determination of Water Collection Sites}

The collection sites were established after identification of the number and location of supply sources. After mapping of the water distribution network, three collection sites were determined for each water supply source in such a way that the collected samples were representative and covered all areas and water sources of the city. The addresses were selected by random selection of streets. In order to facilitate access to the site and avoid loss of samples, it was decided that the collection sites would be public places, such as schools, squares and commercial establishments.

\section{Collection of Water Samples}

For collection of the samples, $30 \mathrm{~mL}$ polyethylene bottles were previously decontaminated with deionized water and identified with labels indicating the collection site, date and collector's name.

The samples were collected once a month on weekdays at previously established collection sites and analyzed in duplicate between November 2004 and October 2010 at the Research Laboratory of the Nucleus for Public Health (NEPESCO) of the Public Health Graduate Program from Araçatuba Dental School/UNESP, Brazil, totalizing 9 samples analyzed in duplicate every month.

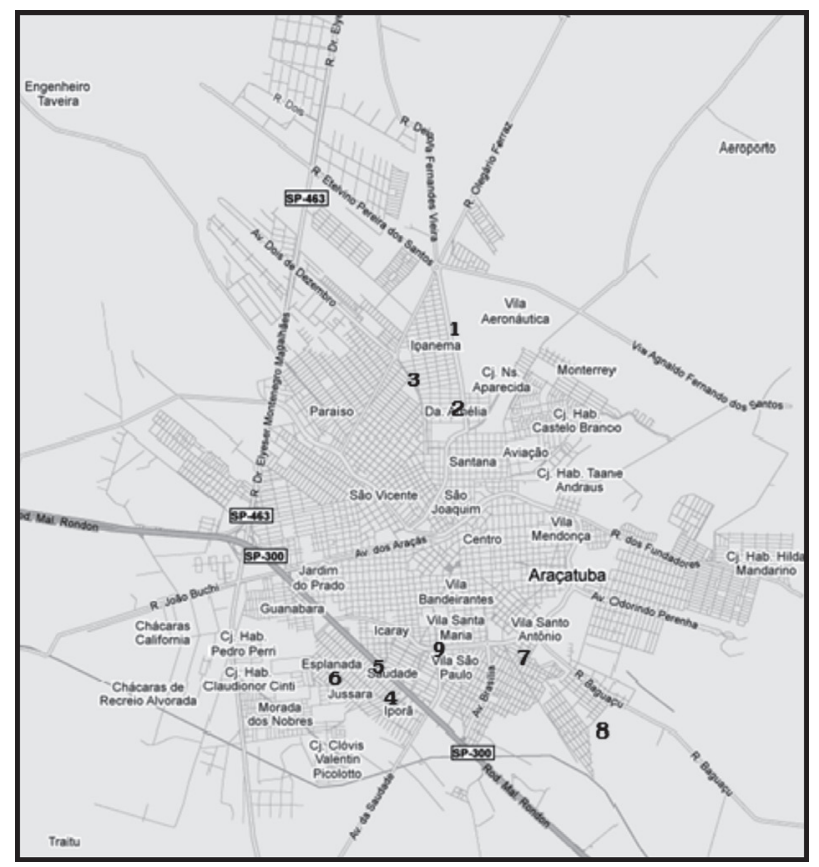

Figure 1. Map of Araçatuba, SP, Brazil, 2011, according to the water supply sources divisions and the respective water collection sites of the study. 
Analysis of Fluoride Concentration in Water

Analysis of fluoride concentration in the water samples was performed using an ion analyzer (Orion Model 940EA; Orion Research Inc., Beverly, MA, USA) coupled to a specific electrode (Orion model 9609BN; Orion Research Inc.) for fluoride. The calibration of the equipment was performed in triplicate, in order to reduce the margin of error, taking into account the expected values for the samples with standards ranging from 0.1 to $2.0 \mathrm{mgF} / \mathrm{L}$. For this purpose, dilutions from a standard solution of fluoride of $100 \mathrm{mg} / \mathrm{L}$ (Orion 940907; Orion Research Inc.) were used. From each of these standards a volume of $1 \mathrm{~mL}$ was collected after addition of $1 \mathrm{~mL}$ of "Total Ionic Strength Adjustor Buffer" (TISAB II; Orion Research Inc.); a $\mathrm{pH}$ adjustment buffer, ionic and non-complex strength, widely used in the analysis of fluoride.

\section{Data Analysis}

The values obtained from duplicate analyses of samples, after the addition of TISAB II $(1: 1)$, were transferred to a Microsoft Excel spreadsheet, converted from $\mathrm{mV}$ to $\mathrm{mgF} / \mathrm{L}$ and analyzed by descriptive statistics. The mean of fluoride concentration, standard deviation, minimum and maximum value were calculated for each collection site analyzed, and the absolute and percentage distribution of the results was performed according to the classification established by the Ministry of Health Collaborating Center for Oral Health Surveillance (12).

Table 1. Classification of water distribution network and population coverage. Araçatuba, SP, 2011.

\begin{tabular}{lccc}
\hline $\begin{array}{l}\text { Water } \\
\text { source }\end{array}$ & $\begin{array}{c}\text { Collection } \\
\text { site }\end{array}$ & $\begin{array}{c}\text { Presence } \\
\text { of fluoride }\end{array}$ & $\begin{array}{c}\text { Population } \\
\text { coverage }\end{array}$ \\
\hline $\begin{array}{l}\text { Jardim } \\
\text { Ipanema } \\
\text { deep well }\end{array}$ & 1 & Natural & \\
& 3 & Natural & $15 \%$ \\
Jardim & 4 & Natural & \\
Jussara & 5 & Natural & \\
deep well & 6 & Natural & $15 \%$ \\
& 7 & Artificially added & \\
Ribeirão & 8 & Artificially added & $70 \%$ \\
Baguaçu & 9 & Artificially added & \\
& & &
\end{tabular}

\section{RESULTS}

In the period between November 2004 and October 2010, 591 water samples from the 9 selected collection sites were monthly analyzed, in duplicate, totalizing 1,182 samples. Table 1 shows the water distribution network classification according to the natural presence of the fluoride or artificially added fluoride as well as the population coverage by each water supply. Table 2 shows the distribution of water samples according to fluoride concentration $(\mathrm{mgF} / \mathrm{L})$, between November 2004 and October 2010.

The classification of the samples by year is summarized in Figure 2. It is observed that in all years, except for 2005, most analyzed samples presented fluoride concentration between 0.55 and $0.84 \mathrm{mgF} / \mathrm{L}$.

Table 3 shows the means of fluoride concentration, standard deviations, minimum and maximum values found in water samples, according to the collection site. It was observed that during the 72 months, all analyzed collection sites showed mean of fluoride concentrations within the recommended parameters.

Figure 3 shows the variation of the mean fluoride concentration $(\mathrm{mgF} / \mathrm{L})$ of water samples, according to the collection site, during the 72 months.

\section{DISCUSSION}

This study analyzed the fluoride concentrations of public water supply in the city of Araçatuba, SP, one of the first Brazilian cities to initiate the water fluoridation process, considering the potability standards established according to the average daily maximum air temperature. In this way, water samples with fluoride concentration

Table 2. Distribution of samples from public water supply from Araçatuba, SP, according to fluoride concentration (mgF/L), between November 2004 and October 2010. Araçatuba, SP, 2011.

\begin{tabular}{lcc}
\hline $\begin{array}{l}\text { Fluoride concentration } \\
(\mathrm{mgF} / \mathrm{L})\end{array}$ & $\mathrm{N}$ & $\%$ \\
\hline $0.0-0.44$ & 29 & 4.9 \\
$0.45-0.54$ & 93 & 15.7 \\
$0.55-0.84$ & 397 & 67.2 \\
$0.85-1.14$ & 68 & 11.5 \\
$>1.2$ & 4 & 0.7 \\
Total & 591 & 100 \\
\hline
\end{tabular}


offering the best risk-benefit combination must have fluoride concentration between 0.55 and $0.84 \mathrm{mgF} / \mathrm{L}$. With monthly monitoring of the public water supply it is expected the fluoride concentration to be adequate to promote oral health, assisting the control and reduction of dental caries among the population.

According to the obtained results, it was observed that $67 \%$ of the samples had fluoride concentration that offered the best risk-benefit combination (Table 2). Similar conditions were observed in a study performed in the city of Campo Grande, MS, Brazil, in which 63.5\% of the samples were classified as "acceptable" (14). The maximum fluoride concentration value found in the

Table 3. Mean values, standard deviations (SD), minimum and maximum fluoride concentration $(\mathrm{mgF} / \mathrm{L})$ in the analyzed water samples, according to the collection site, between November 2004 and October 2010. Araçatuba, SP, 2011.

\begin{tabular}{lllll}
\hline $\begin{array}{l}\text { Collection } \\
\text { site }\end{array}$ & Mean & SD & Minimum & Maximum \\
\hline 1 & 0.74 & 0.07 & 0.49 & 0.86 \\
2 & 0.75 & 0.07 & 0.49 & 0.87 \\
3 & 0.71 & 0.09 & 0.45 & 0.89 \\
4 & 0.73 & 0.28 & 0.09 & 2.38 \\
5 & 0.75 & 0.39 & 0.07 & 3.45 \\
6 & 0.73 & 0.20 & 0.29 & 1.79 \\
7 & 0.66 & 0.29 & 0.07 & 2.53 \\
8 & 0.62 & 0.16 & 0.07 & 0.93 \\
9 & 0.61 & 0.15 & 0.07 & 0.93 \\
\hline
\end{tabular}

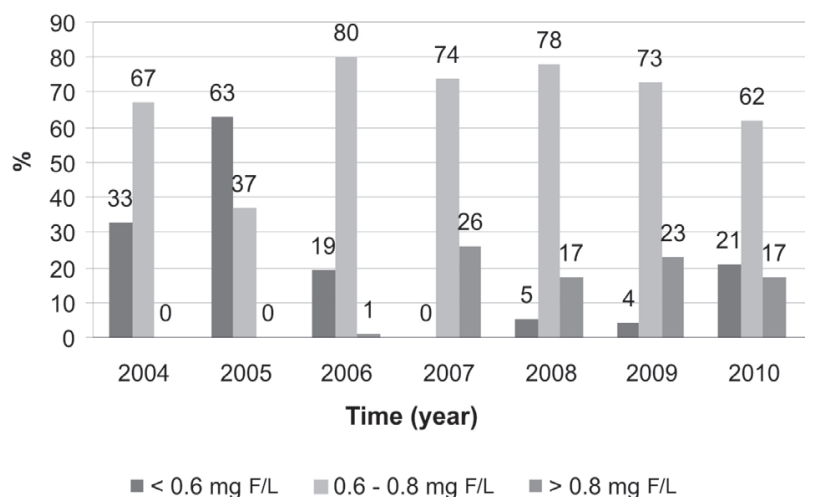

Figure 2. Percent distribution of water samples of Araçatuba, SP, Brazil, according to the year and fluoride concentration, between November 2004 and October 2010. present study was $3.45 \mathrm{mgF} / \mathrm{L}$ (Table 3 ), corresponding to the collection site with the highest standard deviation among all sites. In the present study, all collections sites had mean fluoride concentration within the range that offers the best risk-benefit combination. However, the analysis of the annual variation of mean fluoride concentration in public water supply within the study period (Fig. 3) exhibits some variation at the same site in different periods. This finding reinforced the importance of surveillance for the population to receive the benefits of this preventive method.

Several studies have demonstrated that optimum concentration of fluoride in public water supply for the reduction of dental caries, when considering the risk and benefits, is between 0.7 to $1.2 \mathrm{mgF} / \mathrm{L}$, according to the annual average temperature of each location. In the present study, only four samples $(0.7 \%)$ presented fluoride concentration above $1.2 \mathrm{mgF} / \mathrm{L}$ (Table 2). It should be noted that these high concentrations were observed separately and promptly corrected by the city after the monthly analysis results were provided, thus not representing, therefore, risk to the development of dental fluorosis by the population. Small oscillations were observed in one collection site along the study, but it is not an evident risk situation, considering that the discrepant results did not remain constantly $(15,16)$.

According to Saliba et al. (17), who analyzed the fluoride concentration in the water supply of 40 cities located in the northwestern region of the São Paulo state, where Araçatuba is included, most of them do not maintain a proper control over the fluoride concentration in the water. Also, fluoride concentration in $78.79 \%$ of the cities presented variations among the

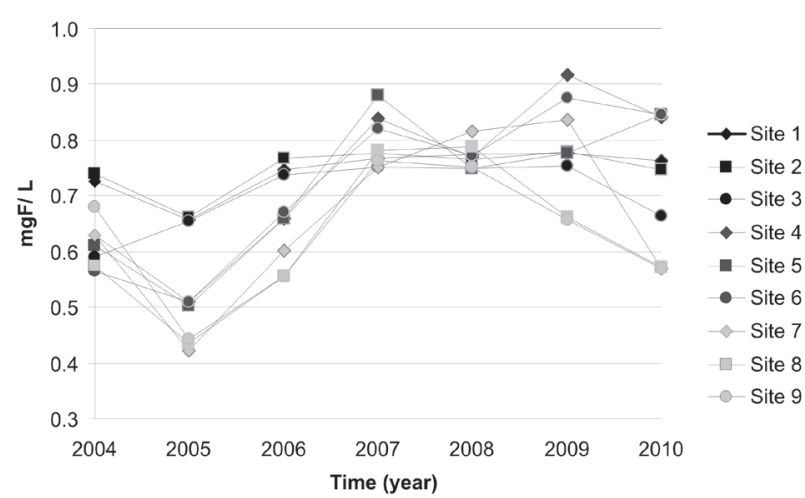

Figure 3. Variation of the mean fluoride concentration $(\mathrm{mgF} / \mathrm{L})$ of water samples, according to the collection site, between November 2004 and October 2010. Araçatuba, SP, 2011. 
collection sites and at the same site along the study period. An annual analysis of the results (Fig. 2) shows a decreased percentage of samples classified as lower than recommended, concomitant with an increase of samples above recommended. However, only $12.2 \%$ of the analyzed water samples showed fluoride concentration above the parameters that offer the best risk-benefit combination, with $11.5 \%$ between 0.85 and $1.14 \mathrm{mgF} / \mathrm{L}$ and only $0.7 \%$ above $1.2 \mathrm{mgF} / \mathrm{L}$ (Table 2), a fact that justifies the non-exposure of the local population to the risk of dental fluorosis due to consumption of artificially fluoridated water.

Catani et al. (18) suggested the conduction of studies in laboratory animals exposed to variable concentrations of fluoride in water in order to confirm the results observed in case of an association between regular maintenance of optimum fluoride concentration in water with the increased prevalence of fluorosis.

The contribution of fluoridated water to the dose of exposure to risk of dental fluorosis has been the focus of attention of researchers (19). However, a study conducted in Bauru, SP, Brazil, showed that the prevalence of fluorosis in schoolchildren living in nonfluoridated areas confirms the presence of other sources of fluoride (20), and thus the fluoridation of public water supply is not responsible for the prevalence of dental fluorosis in areas with optimal fluoride concentration in water.

From the obtained results, it was observed that most water samples presented fluoride concentration within the parameters of potability and that there was minimal variation among the analyzed collection sites, demonstrating that the city has succeeded in controlling water fluoridation. Monthly samples were not collected from some sites due to transportation difficulties or political problems that interfered with site access. It was verified that in the city of Araçatuba, the addition of fluoride to drinking water occurs continuously and within the recommended parameters, highlighting the importance of surveillance and constant monitoring to ensure the quality of water supplied to the population.

\section{RESUMO}

Reconhecida como um dos dez mais importantes avanços na Saúde Pública do século 20, a fluoretação das águas de abastecimento é uma medida de grande alcance populacional, eficaz no controle da cárie dentária. A cidade de Araçatuba, na região noroeste do estado de São Paulo, iniciou a fluoretação em 1972 e baseado na média da temperatura máxima anual, deve manter o teor de flúor entre 0,6 a $0,8 \mathrm{mgF} / \mathrm{L}$. O objetivo deste estudo foi analisar mensalmente os teores de fluoretos nas águas de abastecimento público, no município de Araçatuba, durante 72 meses. Amostras de água foram coletadas mensalmente, em dias úteis, diretamente da rede de distribuição, nos pontos previamente estabelecidos e analisadas, em duplicata, de novembro de 2004 a outubro de 2010, no laboratório do Núcleo de Pesquisa em Saúde Coletiva do Programa de Pós-Graduação em Odontologia Preventiva e Social (NEPESCO) da Faculdade de Odontologia de Araçatuba/ UNESP, utilizando-se um analisador de íons acoplado a um eletrodo específico para flúor. Do total das amostras $(\mathrm{n}=591)$, $67,2 \%(n=397)$ apresentaram teores de flúor entre 0,6 e $0,8 \mathrm{mgF} / \mathrm{L}$; $20,6 \%(n=122)$ abaixo de $0,6 \mathrm{mgF} / \mathrm{L} ; 11,5 \%(\mathrm{n}=68)$ entre 0,8 e $1,2 \mathrm{mgF} / \mathrm{L}$ e $0,7 \%(\mathrm{n}=4)$ acima de $1,2 \mathrm{mgF} / \mathrm{L}$. A maioria das amostras apresentou teores de fluoreto dentro dos parâmetros recomendados. Observou-se variação mínima entre os pontos de coleta analisados, demonstrando que o município tem obtido êxito no controle dos níveis de flúor presentes na água e evidenciando a importância da vigilância e monitoramento constantes para garantir a qualidade da água fornecida à população.

\section{ACKNOWLEDGEMENTS}

The authors would like to thank the National Council for Scientific and Technological Development (CNPq) for the financial support to this study.

\section{REFERENCES}

1. Brazil. Ministry of Health. Federal law 6050, to May 24, 1974. Provides for the mandatory fluoridation of water in the supply system. Official document of the Federative Republic of Brazil, 27 July 1975. Available from: http://www.jusbrasil.com.br/ legislacao/128460/lei-6050-74. Latest access: October 30, 2012.

2. Saliba NA, Moimaz SAS, Casotti CA, Pagliari AV. Dental caries of lifetime residents in Baixo Guandu, Brazil, fluoridated since 1953. J Public Health Dent 2008;68:119-121.

3. Forte FDS, Moimaz SAS, Sampaio FC. Urinary fluoride excretion in children exposed to fluoride toothpaste and to different water fluoride levels in a tropical area of Brazil. Braz Dent J 2008; 19:214-218.

4. Centers for Disease Control and Prevention (CDC). Ten great public health achievements - United States, 1900-1999. MMWR Morb Mortal Wkly Rep 1999;48:241-243.

5. Cury JA, Tabchoury CPM. Determination of appropriate exposure to fluoride in non-eme countries in the future. J Appl Oral Sci 2003;11:83-95.

6. Zimmer S, Jahn KR, Barthel CR. Recommendations for the use of fluoride in caries prevention. Oral Health Prev Dent 2003;1:45- 51.

7. WHO. Fluoride in drinking-water. Geneva: World Health Organization; 2006.

8. Lima-Arsati YBO, Martins CC, Rocha LA, Cury JA. Fingernail may not be a reliable biomarker of fluoride body burden from dentifrice. Braz Dent J 2010;21:91-97.

9. Cury JA, Oliveira MJL, Martins CC, Tenuta LMA, Paiva SM. Available fluoride in toothpastes used by Brazilian children. Braz Dent J 2010;21:396-400.

10. Narvai PC. Dental caries and fluorine: a twentieth century relation. Cien Saúde Colet 2000;5:381-392.

11. Galagan DJ, Vermillion JR. Determining optimum fluoride concentrations. Public Health Rep 1957;72:491-493. 
12. Ministry of Health Collaborating Center for Oral Health Surveillance [CECOL/USP]. Technical consensus about the classification of public water supplies according to fluoride content. São Paulo: Public Health School, University of São Paulo; 2011.

13. Brazilian Institute of Geography and Statistics (IBGE). Available from: http://www.ibge.gov.br/cidadesat/topwindow.htm?1. Latest access: October 30, 2012.

14. Bellé BLL, Lacerda VR, Carli AD, Azfalon EJ, Pereira PZ. Water fluoridation analysis of Campo Grande (MS) urban zone public supply. Cien Saúde Colet 2009;14:1261-1266.

15. Moimaz SAS, Saliba O, Chiba FY, Saliba NA. External control of the public water supply in 29 Brazilian cities. Braz Oral Res 2012;26:12-18.

16. Catani DB, Tenuta LMA, Andalo FA, Cury JA. Fluorosis in rats exposed to oscillating chronic fluoride doses. Braz Dent J 2010;21:32-37.
17. Saliba NA, Moimaz SAS, Tiano AVP. Fluoride level in public water supplies of cities from the northwest region of São Paulo state, Brazil. J Appl Oral Sci 2006;14:346-350.

18. Catani DB, Hugo FN, Cypriano S, Sousa MLR, Cury JA. Relationship between fluoride levels in the public water supply and dental fluorosis. Rev Saúde Pública 2007;41:732-739.

19. Evans RW, Stamm JW. Dental fluorosis following downward adjustment of fluoride in drinking water. J Public Health Dent 1991;51:91-98.

20. Franzolin SOB, Gonçalves A, Padovani CR, Francischone LA, Marta SN. Epidemiology of fluorosis and dental caries according to different types of water supplies. Cien Saúde Colet 2010;15:1841-1847.

Received December 29, 2011

Accepted June 16, 2012 